\title{
FINANCIAL COMPENSATION HAS A HUGE IMPACT TO NON-PERMANENT TEACHER'S (GTT) WORKING PRODUCTIVITY IN SMP N 2 JEMBER
}

\author{
Reni Dwi Agustina ${ }^{1}$ \\ Bagus P Yudhia $\mathrm{K}^{2}$ \\ Supardi ${ }^{3}$ \\ Higher Education of Economic Mandala \\ Email : stie-mj@stie-mandala.ac.id
}

\begin{abstract}
This article research entitled " Financial compensation has a huge impact to NonPermanent Teacher's working productivity (GTT) in SMP N 2 Jember". This study attemps to analyze and examine the impact and the effect of financial compensation on the level of productivity of Non-Permanent Teachers (GTT) of SMP N 2 Jember, either simultaneously or partially. This research belongs to explanatory research survey. The location of this research is SMP N 2 Jember. The Independent variable in this study is financial compensation (X) which consist of salary (X1), courses allowances (X2) and overtime wages (X3), while the dependent variable in this is work productivity of employee (Y). The Population in this research are all non permanent teachers (GTT) at SMP N 2 Jember which also become the sample. To analize the data, the researcher uses SPSS (Statistical Product and Service Solution) version 10. Based on the results of the data, it is known that financial compensation (salary, courses allowances and overtime wages) are significant and has a very important role to incourage the productivity of Non-Permanent Teachers (GTT) in SMP Negeri 2 Jember either partially or simultaneously. In the partial test results which were proved by the score of t-count of each independent variable that are salary, courses allowances and overtime wages are higher than its t-table, so Ho is rejected and $\mathrm{H} 1$ is accepted. The effective contribution of the three variable financial compensation (salary, courses allowances and overtime wages) to the productivity of Non-Permanent Teachers (GTT) in SMP Negeri 2 Jember is also very large at $96.0 \%$ in the courses allowances variable as the most dominant variable. The conclusion is there are strong and significant impact of financial compensation towards work productivity of non permanent teachers in SMP N 2 Jember. So that to increase the work productivity, hence financial compensation must be balanced and must be improved also.
\end{abstract}

\section{Keywords: financial compensation, productivity}

\section{INTRODUCTION}

Human Resources (HR) is a central factor in an organization. Whatever its form and purpose, the organization is made on the basis of various visions for the benefit of man and in the execution of his mission, the organization is managed by humans. Thus, human beings are a strategic factor in all activities of the institution / organization. Good human resource management must provide direction in meeting organizational goals, while at the same time meeting the needs of its 
employees. In this case the effectiveness of people is the key to the success of an organization. Therefore, management must move forward with more innovative and productive ways to lead people, thus getting optimum benefits.

Human resources as well as one of the elements that determine the success of an organization, they also as a creature that has certain thoughts, feelings, needs and expectations. This requires special attention because these factors will affect achievement, dedication, loyalty and love to their work and organization (Hasibuan, 1994). This situation makes human resources as an asset that must be increased efficiency and productivity.

To achieve this, the institution must be able to create conditions that can encourage and enable employees to develop and improve their skills optimally. One effort that can be taken to create a healthy condition is to provide satisfactory compensation. According Handoko (1994), a way to improve job performance, motivation and employee's job satisfaction is to provide compensation. The importance of compensation as one indicator of satisfaction in work is difficult to estimate, since employee views on money or direct rewards seem very subjective and perhaps unique (Fraser, 1992). But basically the allegation of injustice in paying wages and salaries is a source of employee's dissatisfaction towards compensation which in turn can lead the disputes and low spirits from the employees themselves (Strauss and Sayles, 1990).

Michael and Harold (1993) divide compensation in three forms, namely material, social and activity. Material compensation is not just in the form of money, and benefits but all forms of physical reinforcement (phisical reinforcer), such as parking facilities, telephones and comfortable office space. While social compensation is closely related to the need to interact with others. These forms of compensation include recreation, the formation of decision-making groups, and special groups established to solve the institution problems. While the activity compensation is the compensation that is able to compensate for aspects of the unfavored work by providing opportunities to perform certain activities. Forms of activity compensation can be "power" owned by an employee to perform activities outside their routine work so it avoid the rising of work's boredom. The three forms of compensation, will be able to motivate employees both in supervision, job performance, membership, security, personal development and commitment to the workplace. From the results of research conducted by behavioral experts show that the main factor of employee dissatisfaction is the incompatibility of compensation to the expectations of employees. Besides, the employee's dissatisfaction with the receiving compensation can lead to negative behavior of employees to the workplace which can be seen by the decreasing of commitment which will eventually decrease his work performance (Noe, 1994).

This condition requires an institution to develop its performance, and it must be supported by the professional high loyalty and dedication employees. The satisfactory compensation can reduce the incidence of turnover and absenteeism. By increasing employees' commitment to the organization and involving 
employees in organizational activities will reduce the turnover and absenteeime. In addition, another effect of employee dissatisfaction to work is the psychological impact experienced by employees which willing to move away from the institution. The desire is certainly not easy to be realized considering the various conditions that are not or less allow for employees to move from one institution to another institution, such as conditions in the increasingly tight labor market, bureaucracy and internal rules that exist within the institution itself. Finally, the form of their inability to exit is realized with no regard for their work and do not feel responsible towards the progress of the institution or in other words, has low commitment and low involvement to the institution. This of course brings a very unfavorable impact for the institutions because employees who have a low commitment will gain low work performance and productivity.

This condition is feared to occur in Non-Permanent Teachers (GTT) in Jember District. Due to the absence of regional minimum wage fixing, GTT's financial compensation is calculated based on the number of teaching hours the amount of which is adjusted to the school's ability to attract student enrollment fees that are heavily constrained by local regulations and $15 \%$ of the school's BOS funds (Bantuan Operasional Sekolah). This condition caused many GTTs have to compete in searching other side job to fulfill their daily needs with various businesses outside their main teaching hours, even teach in several schools at once because in reality, the number of teaching hours at school should prioritize the civil servant teachers, Although in fact the burden of work such as teaching administration, and other tasks beside the main task of teaching much be charged to the GTT considering all administrative tools should be based on IT-form which is be very difficult to be mastered by the senior civil servant teachers.

This causes GTT have to share its energy and concentration to several jobs at once. This condition is feared to occur in Non-Permanent Teachers (GTT) in SMP $\mathrm{N} 2$ Jember. This conditions can not be allowed to drag on because with low commitment and productivity, the GTT can not devote all their souls, feelings and times to the progress of education in schools that ultimately the school will lose their competitiveness in the aspect of achievement from other schools because it is not uncommon for schools have a highly qualified GTT on aspects of their ability.

Essentially when an individual GTT is satisfied with their income, they will increase their productivity that will support the progress of school. If the school wants to achieve the optimal goal iorder to improve its existence then it should be able to give what is wanted by GTT. The Fulfillment of the needs of GTT will make them do their work better or in other words more productive. It is of course will provide benefits for the school in improving the progress of education through their student achievement.

The general purpose of this study is to analyze and examine the impact of salary on the level of work productivity of Non-Permanent Teacher (GTT) of SMP N 2 Jember, either simultaneously or partially, to analyze and test the impact of courses allowances on work productivity level of Non-Permanent Teachers (GTT ) SMP N 2 Jember, either simultaneously 
or partially and to analyze and test the effect of overtime wages on the level of work productivity of Non-Permanent Teacher (GTT) SMP N 2 Jember, either simultaneously or partially.

\section{Theoretical Framework and Hypothesesis Development Human Resource Management}

Human resources have a very strategic position in the organization, meaning that the human element plays an important role in conducting activities for the achievement of goals. Adequate management of human resources is needed to achieve better conditions so as to create qualified human resources, loyal and achievers. Sulistiyani and Rosidah (2003) stated "MSDM is an effort to mobilize and manage human resources within the organization in order to be able to think and act as desired by the organization". Simamora (2004) suggests that:

Human resource management is the empowerment, development, assessment, reward, and management of individual members of an organization or group. Human resource management also involves the design and implementation of a system of planning, development, development, career management, performance evaluation, compensation, and smooth employment relationships

\section{Definition of Non-Permanent Teachers (GTT)}

Teachers according to Law Number 14 / 2005 regarding teachers and lecturers are professional educators with the main task of educating, teaching, guiding, directing, training, assessing and evaluating learners in early childhood education formal education, primary education and secondary education (pasal 1 , ayat 1).

A teacher participates in the effort to establish potential human resources in the field of development. Understanding professional teachers by experts is all people who have the authority and responsible about the education of their students, either individually or classically, in school or out of school. In the Indonesi, teachers generally refer to educators with the main task of educating, teaching, guiding, directing, training, assessing, and evaluating learners. Teacher is someone who is always heard and imitated.

The term GTT is formal because the three letters are the choice of the administrative standard of mention in public schools. The term GTT is commonly found in official letters, assignment letters, and various other official letters in public schools. GTT is appointed based on the needs of the school by the principal. Appointment decree is local, not provincial (governor), or national (President). This appointment is through a series of tests held by the school. All authority rests on the principal, both the appointment, the sustainability as well as the dismissal of the GTT. The salaries of GTT are funded by schools that are sourced from the participation of parents and BOS (Operational school) funds that should only be used as much as $15 \%$ of the amounts received by the school. Each newly year of lessons, GTT signs work contacts for a certain period of time, a year or more based on the school's needs.

\section{Compensation Definition}


The compensation of an organization which is oriented to profit making is an important factor to motivate the improving of its performance and maintaining the competent. According to Simamora (2004) that "compensation includes the financial returns, realized services and benefits received by the employees as part of the employment relationship. Compensation is what people receive in exchange for their contribution to the organization ". Martoyo's opinion (2000) "compensation is the overall arrangement of reward for employers and employees either directly in the form of money / financial or indirectly in the form of not money / nonfinancial". Further Handoko (2000) defines "compensation is the remuneration given by the institution to the workforce for the services or work either in the form of material (salary, incentive, bonus, commission, allowance) or non material (orally appreciation, praise, secure feeling)" Sikula (in Martoyo, 2000) says that:

.... In the employment world, financial rewards are the compensation resources provided to the employees for the return of their services. The terms "Remuneration", "wage" and "salary". Also are used to describe this financial arrangement between employers and employees. A remuneration is a reward, payment or reembursement for services rendered.

(In Kean, a prize of money which is the compensation given to them as a reward for their service. The kinds of giving wages, forms of wages and salaries are used to regulate the giving between the employer and his/her employees. Renumeration is a reward, payment or compensation for the service given).

According to Hasibuan (2002) "Compensation is divided into two, namely direct compensation in the form of salary, wage and incentive wage and Indirect compensation / employee welfare. While Sulistiyani and Rosidah (2003) stated that:

There are two kinds of Compensations, namely, direct / financial compensation and indirect / non-financial compensation. Definitively direct compensation is the basic wage or salary system plus by a payment based on performance

(achievement). Indirect compensation is a general category of benefits, a mandated protection program, health insurance, unemployed wage and other benefits.

More deeply Umar (2003) explains that:

The remuneration is divided into two types: financial rewards (often called financial compensation), and nonfinancial rewards (often called complementary compensation or indirect compensation) which is not related to work performance directly. Financial rewards is something received by the employees in the form of such as salaries or wages, bonuses, premiums, medications, insurance and others and paid by the 


\begin{abstract}
organization. Nonfinancial benefits, intended to maintain in the long term coorperation such as the provision of service programs for those who attempt to create a pleasant conditions and working environment such as recreation programs, cafeterias and places of worship.
\end{abstract}

According to Martoyo (2000) the association of compensation with work productivity is in "better compensation will encourage the employee's high productivity, the cost per unit or production will be even lower". With the compensation given to the employee productivity increases so that it can meet the needs of daily life or in other words the economic needs. With the certain of receiving wages or salaries periodically means the guarantee of "economic security" and the families whose become dependents, thus encourages him to work more productively.

Objectives and Benefits of Compensation

Every organization, whether small, medium or large, will design a compensation system for its people with a purpose, to lure, hold and motivate them. According to Giri (2009) "The compensation system is also designed for the achievement of certain objectives that are more common in nature, such objectives include attempting to reward desired work and centralize costs".

The purpose of compensation development is not a rule that must be rigidly followed and executed, but rather to the guidelines in giving wages / salaries to the employees. The better setting of salary and wages of an organization will be the better the salary / wages are received by its employees. The compensation arrangement must meet several objectives. Sometimes these goals will contradict each other. There are several goals or targets to be achieved by the organization in setting policy and reward system designed in such a way and effective. Ruky (in Giri, 2009) states that agency goals in establishing compensation systems are:

1. Be able to "attract" good quality worker and "retain" them (in order not to move to other agencies).

2. Motivate the good worker gains high achievement.

3. Encourage the improvement of the human resources quality.

4. Help to control the cost of labor benefits (labor cost).

According to Milkovich and Newman (1996) Pay systems are designed efficiency (performance driven, total quality, customer focus, cost control), equity and compliance. The development of pays benefits is highly dependent on each institution and type of business. According to Carell, et.all (1995) Reward / compensation aims to attract from outside the institution, maintaining a good quality, motivating, as well as efforts to comply with applicable legislation.

\section{Factors That Become Compensation Considerations}

According to Dessler (1998) in determining the formulation of wages compensation plan, especially related to salary and wages, there are four factors that must be considered, namely legal factors, trade unions, policies and justice.

According to Gomez, et.all (1995), External equity refers to the 
perceifed fairness of pay relative to what other employees are paying for the same type of labor. To achieve external equity, they use salary data on benchmarks or key jobs. Obstained from market surveys to set a pay policy. The policy of the external reward rate is influenced by the level of demand and supply of labor, product markets, industry characteristics, the ability to pay.

According to Giri (2009) "Giving compensation by an organization based on a good mindset, usually the compensation is given on the basic principles that meet the five components, namely:

1. Fair / equitable, the determination of the level / amount of wages should be considered "fair" which in book terms is called "internal equity" or "equitable".

2. Attractive and Competative, the wage / salary / reward rate offered should be attractive and competitive compared to other similar institution. To ensure that it can be achieved, institution should routinely do the benchmarking surveys in the same or more extensive industry sector

3. Appropriate, easy and up-todate, the policy and reward system used should be appropriate for the institution in terms of various aspects.

4. Comply with the provisions of the laws and regulations of the government, all policies.

5. Fair / reasonable, the level of reward / wage / salary should be sufficient and reasonable for the recipient in accordance with the ability of the institution.

There are four factors to determine the compensation system according to Mondy, Noe and Premeaux (in Giri; 2009), namely: the organization factor, the employee factor, the labor market factor and the type of work itself (the Job).

1. In the organizational factors, the determination of compensation should be viewed from the side of management policy, the political circumstances that affect the organization and the ability of the organization in making payments.

2. From the employee factor, the determination of this compensation must touch on matters relating to the worker's performance, payments based on merit, salary variables, skill-based payments, payments based on competence, seniority, work experience, membership relation in the organization, Its potential, political influence and the last is luck.

3. In the labor market factors, the determination of compensation should also look at the generally applicable compensation in the labor market, for which the organization in establishing this compensation system should conduct a survey on other institution, feasibility, living costs, labor organization, social level and prevailing economic legislation. 
4. While in the job factor, the determination of the compensation system should be based on job analysis, job description, job evaluation and collective bargaining, .

\section{Work Productivity}

Institutions that want to survive and win the competition in the business world must be able to increase their productivity. Generally, productivity is defined as the relationship between real and physical results (goods or services) with actual entry. As stated by the opinion of Kapustin cited by Sinungan (in Hasibuan, 2003) suggests that "productivity is seen as an intensive use of conversion sources such as labor and measured machinery appropriately and actually demonstrates an efficient performance." Meanwhile, according to Hasibuan (2003): "Productivity is the ratio between output and input. If the productivity increases, it is made possible only by the increasing of efficiency (time-ingrediens-manpower) and work systems, production techniques and the increasing of labor skills".

Philosophically, Umar (2002) defines: "productivity is as a result of the comparison of effectiveness produces output with the efficiency of input use", further Anoraga and Suyati (1995) define productivity as follows: "Productivity has an understanding related to effectiveness and efficiency. Effectiveness is related to achievement of goals that have been associated with human work, while efficiency is more emphasis on the work ".

Grenberg (in Sinungan 2003) defines "productivity as the ratio between the totality of expenditure at a given time divides by the totality of input over a given period". While the definition of productivity by Sulistiyani and Rosidah (2003) is: "Productivity concerns the problem of the end result, that is how big the final results obtained in the production process. In this case it related with efficiency and effectiveness. Efficiency is measured by the ratio of output and input. Or in other words measuring efficiency requires the identification of the work ". Effect of Compensation on Work Productivity

Humans work to meet their needs, so they expect by working they will get the appropriate remuneration that can be used to meet their needs. With a fair and reasonable remuneration received by the employees, it will give job satisfaction that will eventually be the motivation of work with the best and full responsibility because the needs are met so that productivity increases. The increased productivity will raise more profit to the institution as well as enhance the company's advantage in competing in the industry. This is in accordance with the opinion (in http://pustakaonline.wordpress.com/2 $016 / 03 / 21 /$ compensation effect on productivity in $\mathrm{CV}$ moonlight) which states that:

To gain excellence in its human resources, which also means superiority for the institution, the institution must be able to increase the productivity of its human resources. The productivity of an organization is influenced by many factors, such as fair and reasonable compensation so can satisfy its employees.

While Irmayanti (2004) revealed the influence of compensation on job 
satisfaction and work productivity as follows:

Compensation including salaries and incentives is a mirror of competence and contribution received through the job relationship within an institution / organization. The levels of compensation have a major impact on recruitment, job satisfaction, productivity and turnover. Also determines lifestyle, status, selfesteem and feelings towards his institution. Therefore, it can be said that compensation includes one that affects success in achieving the vision and mission of the institution.

Irmayanti's opinion is similar to the results of the 2007/2008 Work Asia survey conducted by human resources consultant Watson Wyatt who revealed that:

Compensation and benefits become one of the main driving factors of

\section{Conceptual framework}

Through propositions that are based on theoretical studies and empirical studies will be explained how many hypotheses to be prepared and engagement in the institution. While high attachment can lead to the achievement of superior financial performance of the agency, which further determines the success of the business.

It is concluded that the survey reveals those with high degree of attachment will take responsibility and focus on contributions to institution's goals, as well as greater loyalty. Where they are 2.5 times more can be top performers, compared to their colleagues who do not engage. So they are not moving around, they can stay in one institution longer. At the same time, that means productivity institution are increasing. High levels of productivity and retention will further improve the institution's financial performance.

According to Simamora (1999) "compensation affects satisfaction and acts as a feedback that allows adjusting behavior later.

how the relationship influence between variables. Before drawing up a conceptual framework, first the framework of the thinking process as shown in Figure 2.1.

\section{Theoretical studies}

1. Pengaruh Kompensasi Terhadap Produktivitas Kerja. Mathis dan Jacson dalam Ahmad Ariadi Lubis (2005)

2. Pengaruh Kompensasi Terhadap Produktivitas Kerja Gessler Gary. (2007)

3. Hubungan Kompensasi dengan Peningkatan Produktivitas Kerja. Siagian (2002)

4. Kompensasi sebagai Motivator Untuk Meningkatkan Kinerja Karyawan. Ninuk Mulyani dalam Ahmad Ariadi Lubis (2005)

5. Pengaruh Kompensasi Terhadap Produktivitas Kerja Pegawai. Gessler dalam Vicky Frestiani Dewi (2014)

6. Pengaruh Kompensasi Finansial dan Nono Finansial terhadap Terhadap Produktivitas Kerja. Melayu S.P Hasibuan dalam Endinus Kagoya (2012)

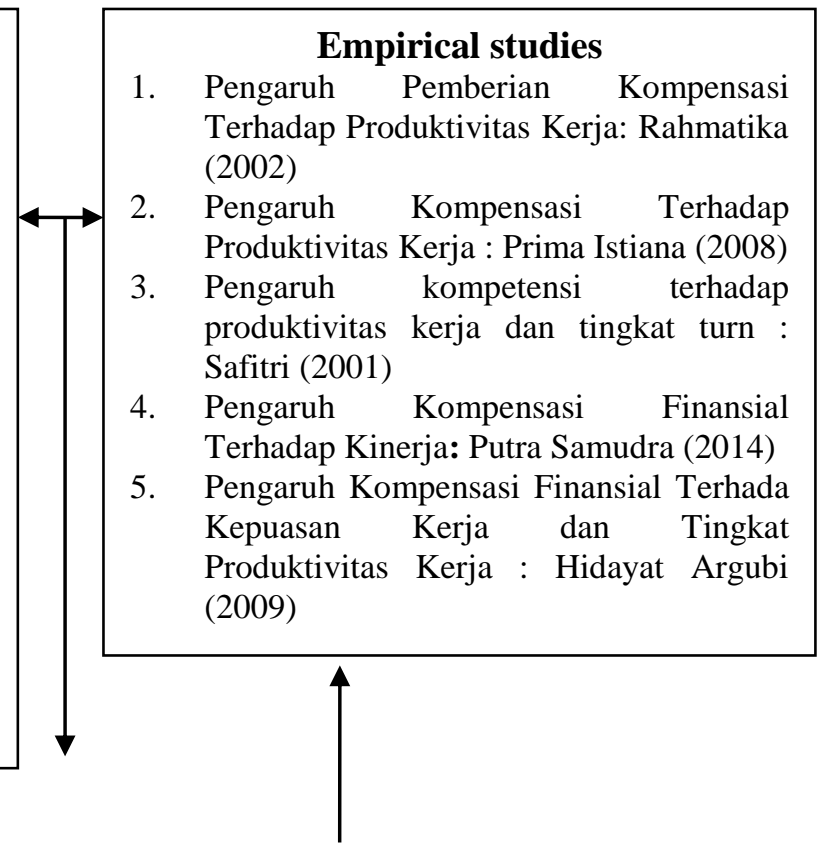




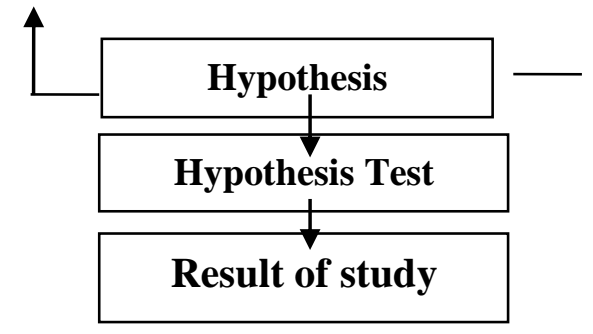

figure 2.1. The Thinking Process Framework 


\section{Hypothesis}

Hypotheses in this study are:

1. The null hypothesis (Ho)

There is no effect of financial compensation (salary, courses allowances and overtime wages) on the work productivity of NonPermanent Teachers SMP N 2 Jember either simultaneously or partially.

2. Working Hypothesis (Ha)

There is the effect of financial compensation (salary, courses allowances and overtime wages) to the work productivity of NonPermanent Teachers of SMP N 2 Jember either simultaneously or partially.

Based on the the problem formulation and research objective in this study, hypotheses is divided into several hypotheses, they are:

1. $\mathrm{H} 1 \mathrm{a}=$ salary compensation has a significant effect on work productivity partially

2. $\mathrm{H} 1 \mathrm{~b}=$ compensation of courses allowances partially has a significant effect on work productivity

3. $\mathrm{H} 1 \mathrm{c}=$ compensation of overtime wages partially has a significant effect on work productivity

4. $\mathrm{H} 2$ = compensation of salary, courses allowances and overtime wages simultaneously have a significant effect on work productivity

\section{RESEARCH METHOD}

This research belongs to survey research while based on its purpose including explanatory research. The location of this research is in SMP N 2 Jember. The independent variables in this study are financial compensation (X) consisting of Salary (X1), Courses
Allowances (X2), and Overtime Wages (X3). While the dependent variable in this study is employee work productivity (Y). Population in this research is all Non Permanent Teacher (GTT) at SMP N 2 Jember which also become sample. Data collection methods used in this study are observation, direct interview, questionnaire, and documentation. At the stage of data processing, use SPSS Ver.10 program performed steps such as examination of data (editing), coding and tabulation. While the stages of data analysis that follow is the test of validity and reliability, multiple linear regression and testing of research hypotheses with F-test and t-test.

Multiple Linear Regression used to know the effect of compensation factor (independent variable) on work productivity of GTT SMP N 2 Jember (dependent variable) whose formulation as follows (Supranto, 2001).

1. To know the magnitude of the influence of compensation factors (independent variables) on the level of work productivity GTT used the following formula:

$$
\mathrm{Y}=\mathrm{a}+\mathrm{b} 1 \mathrm{X} 1+\mathrm{b} 2 \mathrm{X} 2+
$$

$\mathrm{b} 3 \mathrm{X} 3+\mathrm{e}$

Information:

$\mathrm{Y}=$ Level of work productivity GTT

$$
\begin{array}{ll}
\text { A } & =\text { Constants } \\
\text { B1 ... b4 } & =\text { Regression coefficients } \\
\text { X1 } & =\text { Salary } \\
\text { X2 } & =\text { Les Benefits } \\
\text { X3 } & =\text { Overtime Wages } \\
\text { e } & =\text { Interference variable }
\end{array}
$$

Regression analysis was performed as a statistical test in order to know the effect of compensation on the 
level of work productivity of GTT SMP N 2 Jember.

2. Determining the Hypothesis

Ho $=\beta \mathrm{i}=0$ The independent variables simultaneously have no significant effect on the dependent variable

$\mathrm{Hi}=\beta \mathrm{i} \neq 0$ Independent variables simultaneously have a significant influence on the dependent variable

(3). Determining the level of significance. The expected level of significance is $\alpha=5 \%$ or confident interfal 95\%

(4). Testing criteria for two-sided testing:

(A). By comparing the calculated statistics with the table statistics

* If statistics F count <statistic Ftabel, then Ho accepted
* If the statistics F count> Ftable statistic, then Ho is rejected

$*$ If statistics $\mathrm{t}$ count <ttable statistic, then Ho accepted

* If statistics thitung $>$ ttable statistics, then Ho rejected

(B). Based on Probability

* If probability $>0.05$, then $\mathrm{Ho}$ is accepted

* If probability $<0.05$, then Ho is rejected

\section{RESULTS ANALYSIS}

Results of the calculation of multiple linear regression analysis in this study by using the calculation of computer program Statistical and Service Solution (SPSS) version 10.0. The recapitulation of the results of multiple linear regression analysis is presented in the following

table

Table 1. Recapitulation of Results of Multiple Linear Regression Analysis

\begin{tabular}{|l|l|l|l|l|l|}
\hline \multirow{2}{*}{ No. Independent Variable } & \multirow{2}{*}{$\begin{array}{c}\text { Coefficient } \\
\text { Regression }\end{array}$} & \multicolumn{2}{|c|}{$\begin{array}{c}\text { Presentation of } \\
\text { hypotheses }\end{array}$} & \multirow{2}{*}{ Sign. } \\
\cline { 4 - 5 } & & & t-count & t-table & \\
\hline 1. & Salary (X1) & 0,126 & 2,274 & 2,228 & 0,046 \\
2. & Courses Allowances (X2) & 0,218 & 3,108 & & 0,011 \\
3. & Overtime Wages (X3) & 0,110 & 2,627 & & 0,025 \\
\hline Constants & $=0,437$ & \\
$\mathrm{R}^{2}$ & $=0,960$ & \\
Adjusted $\mathrm{R}^{2}$ & $=0,948$ & \\
F- count & $=79,821$ & \\
F- table $(5 \% ; 3,10)$ & $=3,708$ \\
Significance & $=0,000$ & \\
\hline
\end{tabular}

Source: Research data is processed

Based on the result of multiple linear regression analysis obtained regression equation as follows:

$\mathrm{Y}=0.437+0.126 \mathrm{X} 1+0.218 \mathrm{X} 2+$ $0.110 \times 3$

From the multiple linear regression equation above can be seen the effect of the independent variables (salary, courses allowances and overtime wages) to the dependent variable (work productivity), while the meaning of multiple linear regression equation above can be explained as follows:

1. The regression equation constant (b0) scores positive that is 0.437 , meaning that if there are no scores on independent variables or the independent variables equal to zero, then the work productivity is 0.437 . 
2. The regression coefficient of salary variable (b1) has a positive score of 0.126 , meaning that the increase of salary for one unit, then there will be an increase in work productivity of 0.126 with the assumption of other independent variables are constant.

3. The regression coefficient of variable courses allowances (b2) is positive 0.218 , it means that the increase of allowance of courses allowances by

Table 2. Recapitulation of t-Test Results

\begin{tabular}{|l|c|c|c|}
\hline \multicolumn{1}{|c|}{ Variable } & t-count & t-table & Sig. \\
\hline Salary (X1) & 2,274 & 2,228 & 0,046 \\
Courses Allowances (X2) & 3,108 & & 0,011 \\
Overtime Wages (X3) & 2,627 & & 0,025 \\
\hline
\end{tabular}

Source: Research data is processed

Based on the t- test steps and the above table, then the hypothesis testing for each independent variable salary, courses allowances and overtime wages to work productivity are as follows:

1. Salary Variable (X1): Based on the above table it is known that the score of t- count variable of salary is equal to 2,274 with probability value is 0,046 , while t-table score is 2,228 , so $\mathrm{t}$-count $>$ t-table $(2,274>2,228)$. This shows that salary variable partially have a significant effect on work productivity.

2. Variable Courses Allowances (X2)

Based on the above table it is known that the score of t-count of the courses allowances variable is 3,108 with probability value of 0.011 , while the t-table score is 2,228 , so that $\mathrm{t}$ count $>$ t-table $(3,108>2,228)$. This shows that the variable courses allowances partially have a significant effect on work productivity.

3. Variable Overtime Wages (X3)

Based on the above table it is known that the $t$-value of the overtime wage one unit, hence there will be the increasing of work productivity to 0,218 with assumption of other independent variables are constant.

4. The regression coefficient of overtime wage variable (b3) is positive, that is 0.110 , meaning that the increasing of overtime wages per one unit, then there will be an increase of work productivity of 0.110 with the assumption of other independent variables are constant. variable is 2.627 with the probability value of 0.025 , while the t-table value is 2,228 , so that $t$-count $>t$-table (2.627> 2,228). This indicates that the variable of overtime wage partially has a significant effect on work productivity.

\section{Hypothesis Testing Regression Coefficient Simultaneously with Test F}

This test is intended to determine the effect of independent variables (salary, courses allowances and overtime wages) to the dependent variable (work productivity) simultaneously (together).

The test steps are as follows:

1. $\mathrm{H} 0: \mathrm{bj}=0$, meaning partially there is no significant influence of the variables $\mathrm{X} 1, \mathrm{X} 2, \mathrm{X} 3$ to $\mathrm{Y}$.

$\mathrm{H} 1$ : $b j \neq 0$, meaning that there is partially significant influence of variable $\mathrm{X} 1, \mathrm{X} 2, \mathrm{X} 3$ to $\mathrm{Y}$.

2. $\alpha=0.05$

3. Criteria testing:

- H0 is accepted, if F-count <Ftable, it means simultaneously 
there is no significant influence from variable $\mathrm{X} 1, \mathrm{X} 2, \mathrm{X} 3$ to $\mathrm{Y}$.

- $\mathrm{H} 0$ is rejected, if F-count $\geq \mathrm{F}$ table, it means that there are simultaneously significant influence of variable X1, X2, X3 to $\mathrm{Y}$.

4. F-table $=3,708$

F-count $=79,821$

The score of F-count is 79.821 ( $p$ $=0,000)$ and the score F-table is 3.708, then F-count $>$ F-table (79.821> 3.708), means that the independent variables (salary, courses allowances and overtime wages) simultaneously has a significant influence on the dependent variable (work productivity).

\section{The Partially Hypothesis Testing Regression Coefficient with t-test}

To know the influence of independent variable to dependent variable partially used t-test, which is compare between the result of $t$-count with t-table from each variable, salary, courses allowances and overtime wages to work productivity.

The test steps are as follows:

1. $\mathrm{H} 0: \mathrm{bj}=0$, meaning partially there is no significant influence of the variables $\mathrm{X} 1, \mathrm{X} 2, \mathrm{X} 3$ to $\mathrm{Y}$.

Table 3. Effective Contribution of Independent Variables

\begin{tabular}{|l|c|c|c|}
\hline \multicolumn{1}{|c|}{ Variable } & $\begin{array}{c}\text { Standardized } \\
\text { Coefficient }\end{array}$ & $\begin{array}{c}\text { Correlation } \\
\text { Zero Order }\end{array}$ & $\begin{array}{c}\text { Effective } \\
\text { Contributions }\end{array}$ \\
\hline Salary (X1) & 0,262 & 0,888 & 0,233 \\
Courses Allowances (X2) & 0,440 & 0,947 & 0,417 \\
Overtime Wages (X3) & 0,337 & 0,921 & 0,310 \\
\hline \multicolumn{4}{|l|}{ Coefficient of Determination $\left(\mathrm{R}^{2}\right)$} \\
\hline
\end{tabular}

Source: Research data is processed

Based on the above results, it is known that the coefficient of determination $\left(\mathrm{R}^{2}\right)$ is 0.960 , which means that the independent variables (salary, courses allowances and overtime wages) affect the dependent variable (work
2. $\mathrm{H} 1: \mathrm{bj} \neq 0$, meaning that there is partially significant influence of variable $\mathrm{X} 1, \mathrm{X} 2, \mathrm{X} 3$ to $\mathrm{Y}$.

3. $\alpha=0.05$

4. Criteria testing:

- $\mathrm{HO}$ is accepted, if t-table <tcount <t-table, it means partially there is no significant influence of variables X1, X2, X3 to $\mathrm{Y}$.

- $\mathrm{HO}$ is rejected, if $\mathrm{t}$-count <-ttable or $\mathrm{t}$ - count $\geq \mathrm{t}$-table, meaning that partially there is significant influence from variable $\mathrm{X} 1, \mathrm{X} 2, \mathrm{X} 3$ to $\mathrm{Y}$.

\section{Coefficient of Determination $\left(\mathrm{R}^{2}\right)$}

Effective contributions are used to find out which variables have the greatest contribution to work productivity or, in other words, which factor is the most dominant among the independent variables. Determination of effective donations is done by multiplying the score of standardized coefficients with zero-orde correlation on each independent variable. The results of effective donations are presented in the following table: 
$0.233(23.3 \%)$, the courses allowances is $0,417(41,7 \%)$ and the overtime wage is $0,310(31,0 \%)$. Based on these results it can be concluded that the most dominant variable that influences the work productivity is the variable courses allowances with a contribution of $41.7 \%$.

Based on multiple linear regression test, it is known that both jointly tested and partially showing that financial compensation consisting of salary, courses allowances, and overtime wages have a significant influence to the work productivity of Non-Permanent Teacher (GTT) at SMP Negeri 2 Jember. The test data to determine the effect of the independent variables (salary, courses allowances, and overtime wages) on the dependent variable (work productivity) simultaneously shows that the F-count score is 79.821 ( $\mathrm{p}=$ 0,000 ) and the F- Tables is 3.708 , then F-count $>$ F-table (79.821> 3.708), means that the independent variables (salary, courses allowances, and overtime wages) simultaneously have a significant influence on the dependent variable $\mathrm{Y}$, that is the level of work productivity. Similarly, the results of regression analysis partially indicate that the variable Salary, Les Allowance, and Overtime Wages partially have a significant effect on the level of productivity of Non Permanent Teacher (GTT) SMP Negeri 2 Jember.

The data is also in accordance with frequency distribution data showing 14 teachers or $60,5 \%$ is good enough and $39.5 \%$ of other respondents are considered good in the aspect of the ability of nonpermanent teachers (GTT) in carrying out teaching and learning activities (KBM) in accordance with workload and division of tasks. It is understandable that the majority of Non-Permanent Teachers (GTT) of SMP Negeri 2 Jember are graduates of Strata One (S1) and Strata Two (S2). So do not be surpraised if the ability of Non-Permanent Teachers (GTT) in implementing teaching and learning activities (KBM) in accordance with workload and division of tasks is good. This condition is coupled with the provision of knowledge and skills gained from some training followed by respondents. This condition is also created as a result of the supervision system implemented by the management of SMP Negeri 2 Jember which continues to control and assess the work of Non-Permanent Teachers (GTT) every day. Data on the ability of Non-Permanent Teachers (GTT) to utilize the tools and learning equipment available at SMP Negeri 2 Jember Jember in KBM indicates that the Non-Permanent Teachers (GTT) SMP Negeri 2 Jember is considered good enough with the percentage of $67.4 \%$ while the rest $32.6 \%$ of respondents rated well. These data indicate that the level of work efficiency of Non-Permanent Teachers (GTT) is quite good at SMP Negeri 2 Jember. This is also supported by the reward and punishment mechanism for Non-Permanent Teachers (GTT) implemented by the management of SMP Negeri 2 Jember. The existence of rules designed by school management to be an effective control tool for management to evaluate the work efficiency of Non-Permanent Teachers (GTT). The frequency distribution data also showed a positive figure on the level of awareness of Non-Permanent Teachers (GTT) in the efficiency of learning achievement time, which is shown by $97.7 \%$ of Non-Fixed Teachers (GTT) data. 


\section{CONCLUSION}

Based on the results and discussion about the impact of salary, courses allowances, and overtime wages for the work productivity of Non-Permanent Teacher (GTT) in SMPN 2 Jember, it is concluded that: Financial compensation salary, courses allowances, and overtime wages for Non-Permanent Teacher (GTT) in SMP Negeri 2 Jember either partially or simultaneously shows that the three variables partially have a significant effect on work productivity. Simultaneously proved by the score of F-count larger than F-table score means that independent variables salary, courses allowances, and overtime wages simultaneously have a significant influence on the dependent variable (work productivity). The effective contribution of financial compensation (salary, courses allowances, and overtime wages) to the productivity of Non-Permanent Teachers (GTT) in SMP Negeri 2 Jember is $96.0 \%$ with the variable courses allowances as the most dominant variable.

\section{IMPLICATIONS}

Based on the conclusion of the research results, it can be obtained the implications of this study. This research is in accordance with the theoretical and empirical foundation which states that financial

\section{REFERENCES}

Arikunto, S. 2002. Prosedur Penelitian Suatu Pendekatan Praktek Edisi Revisi V. Jakarta: PT. Rineka Cipta Buchanan, dalam Garry Dessier, 1992. Organization Theory, Prentice Hall. compensation has a significant effect on the productivity of teacher performance is not fixed. The final result of this research is to increase the productivity of performance, the financial compensation must be balanced and must be improved also. This is in accordance with the concept of human resource development.

Based on the conclusion of the study, there are some suggestions as the result of the study, that are for the institution SMP Negeri 2 Jember as the evaluation materials in improve the compensasion systems especially for the basic salary which has the lowest signification in order to bear better productivity based on the proportion and rules of fairness for all teachers. For the academic prominence, the result of this study can be continued in other case and location to extend some other variables of compensation which affect work productivity.

By knowing the impact of financial compensation to the work productivity of Non- Permanent Teachers (GTT), the institution SMP N 2 Jember should be more careful in giving the compensation because it is the most sensitive aspect and can possible raise problems in the future, such as undisciplined manner, decreasing of responsibility, or even move away to other institutions and many other things that damage the school's profile.

Dessler, Gary. 2007. Manajemen Sumber Daya Manusia. Edisi Kesepuluh Jilid 2. Jakarta: PT. Indeks

Dewi,Vicky, Frestiani. 2014. Pengaruh Kompensasi Terhadap Produktivitas Kerja Pegawai Pada 
Kantor Dinas Perindustrian, Perdagangan, Koperasi dan UMKM Samarinda. Samarinda: eJuornal Ilmu Administrasi Bisnis Fisip Unmul

Flippo, Edwin B. 1984. Personnel Management ( 6 th ed.). McGrawHill International Student Edition

Fraser, T.M., 1992. Stress dan Kepuasan Kerja, Seri Manajemen No. 14, Pustaka Binaan Pressindo, Jakarta. Handoko, T. Hanni, 1994. Manajemen Personalia dan Sumber Daya Manusia, BPFE, Yogyakarta 2000. Manajemen Personalia dan Sumber Daya Manusia Edisi 2. Yogyakarta: BPFE

Hasibuan, Drs. H. Malayu S.P. 2002, Manajemen Sumber Daya Manusia,Jakarta, P.T Bumi Aksara Irmayanti, 2004. Analisis Sistem Penggajian Pada Unit Bisnis Strategis Antara-Reuters. Program Pascasarjana Manajemen dan Bisnis IPB

Istiana, Prima. 2008. Pengaruh Kompensasi Terhadap Produktivitas Kerja (Studi Pada LKM Artha Pratama dan Kusuma Abadi Malang). Program Pascasarjana Manajemen UNISMA

Kagoya, Endinus. 2012. Pengaruh Kompensasi Finasial dan non Finansial Terhadap Produktivitas Kerja. eJuornal Ilmu Administrasi Bisnis Fisip Unmul

Lubis, Ahmad Ariadi. 2005. Pengaruh Kompensasi Terhadap Produktivitas Kerja Karyawan Pada PTRolimex Kimia Nusamas Medan. Medan: Universitas Sumatera Utara

Moleong, Lexy J. 1989. Metodologi Penelitian kualitatif. Remaja Karya CV: Bandung

Mondy, R. Wayne and Noe, Robert M., 1993. Human Resources
Management, Allyn \& Bacon Mowday R.t., 1982. Employ Organization Linkages : The Psychology of Commitment Abstein, and Turn Over, Academic, inc, London.

Nurhayani. 2009. Pengaruh Kompensasi Finansial Terhadap Kinerja Pada CV. SHAD SURABAYA. Skripsi UPI. Bandung

Ravianto, J. 1986. Produktivitas dan Seni Usaha. Lembaga Sarana Informasi Usaha dan Produktivitas: Jakarta.

Robbins, SP., $1993 . \quad$ Organization Behavior : Consept, Convensus, \& Application, Prelince Hall. Ind. Inc. 1996. Perilaku Organisasi : Konsep - Kontroversi - Aplikasi Jilid I. Jakarta : PT. Prenhalindo 2003. Prinsip-prinsip Perilaku Organisasi Edisi ke lima, Erlangga: Jakarta.

Simamora, Henry. 2002. Manajemen Sumber Daya Manusia. STIE YKPN: Yogyakarta 2004. 2002. Manajemen Sumber Daya Manusia. STIE YKPN: Yogyakarta

Sinungan, Muchdarsyah. 2003 Produktivitas Apa dan Bagaimana. Jakarta: PT. Bumi Aksara

Singarimbun, M.; Efendi. 1995 Metode Penelitian Survai. Jakarta: PT. Pustaka LP3ES Indonesia 


\section{BIOGRAPHY}

Reni Dwi Agustina, S.S,.M.M was born on August 2nd, 1982 in Surabaya. She is the second child of the three siblings from her parent Suherman and Endang Tanti, B.A. She has two beautiful daughters named Nuril Azkya and Butsainah Aqilah Argubi Putri. She live in Pondok Gede Jember since 2006. She spent her childhood in Surabaya for her elementary and Yunior high school. That was SDN Kedungdoro V Surabaya and SMP N 2 Surabaya. Then she moved to Mojokerto to continue her senior high school in SMA N 1 Gondang Mojokerto in 1998 and graduated in 2001. She was accepted in Faculty of letters Jember University in 2001 and graduated in 2005 by the shoolarsip path. After that she has worked as an English Teacher of SMP N 2 Jember since 2006 until now. In 2015 she got the shoolarship from Ministry of Education and Culture to continue her post graduate program in STIE Mandala Jember and graduated in 2017. 